\title{
REFLEXION ON THE AFFAIR OF ENGELBERT KUČERA IN THE CZECH PRESS
}

\author{
Marek Pavel \\ Doctor of Philosophy and Pedagogy; Professor; Professor Emeritus, Department of History, \\ Faculty of Arts, Palacký University, Olomouc, Czech Republic \\ Email: pavel.marek@upol.cz \\ Scopus Author ID: 35178301400 \\ http://orcid.org/0000-0001-7578-0783
}

\begin{abstract}
During World War I and after the establishment of the Independence of Czechoslovakia (1918), the socialist movement in the new republic underwent a stage of opinion differentiation, which resulted in the division of the Czech Social Democratic Party. The left faction became independent in 1921 and formed the Communist Party of Czechoslovakia as part of the 3rd International. Part of the fierce internal-party and later inter-party struggle was also the so-called Kučera's affair caused by the publication of information about the Communist International's demand interpreted by Béla Kun to organise a proletarian revolution in the country, which would also result in the liquidation of the bourgeois Czechoslovak Republic. The report had a negative response with the public and in the press, and the reform-oriented leadership of the Social Democratic Party took advantage of these moods to discredit Communism and the Communist Party. In the period before the First World War, Engelbert Kučera was a young worker in South Moravia and was one of the avid functionaries of the Social Democratic Party. After the outbreak of war, he was drafted into the Austro-Hungarian army and sent to the Southern Front where he soon fell into Russian captivity. After the 1917 Russian October Revolution, his thinking underwent a transformation, and he belonged to the radically oriented Bolsheviks. He joined the Russian Communist Party (Bolsheviks) and was also the founder of the Communist Party of Czechoslovakia in Ruthenia. However, when he returned to his homeland and reflected on Soviet Russia developments during 1917 - 1921 and conditions in the communist movement in Czechoslovakia, his thinking evolved again. Kučera deviated from Bolshevism, leaving the left Marxist wing of social democracy and becoming a critic of violent methods accompanying the societal transformation. He was convinced that the optimal approach to establish socialism was not revolution, but evolution, the path of reforms that was followed by the Czech Social Democratic Party's right-wing. He maintained this belief continuously until his death. The core of the presented article is a stage from Kučera's life journey. It presents data from its most critical phase. The affair caused by Kučera is reconstructed through the evocation of selected articles published in the press published in the Czech lands.
\end{abstract}

Keywords: Engelbert Kučera, political parties, Communist International, Czechoslovak Republic, press.

Formulation of the issue. In the summer of 1921, an article by Engelbert Kučera, published in Prague's main newspaper Právo lidu of the Social Democratic Party, entitled «Prodali vlastní svědomí a př́íslušníky své strany (They sold their own conscience and members of their party)» [Právo lidu, 1921, v. 30, no. 160, July $10^{\text {th }}$, pp. 1-3; Žoldnéři nepřátel československé republiky (Mercenaries of the Czechoslovak Republic's Enemies), Stráž socialismu, 1921, v. 2, no. 112, July 12, pp. 1-2; Za sovětské démanty a zlato (For Soviet Diamonds and Gold), Hlas lidu, 1921, v. 36, no. 78, July $14^{\text {th }}$, pp. 1-2]. The writer, former secretary of the party in Brno and a Russian prisoner during the World War I, a member of the Russian Communist Party - Bolsheviks, the Red Army's political commissioner and founder of the Communist Party of Czechoslovakia in Ruthenia, claimed that the leaders of the Communist International (Béla Kun) gave the communists a task to unleash a revolution in the country in the shortest time possible and erase it from the map of Europe as an artificially established state. When they refused it and claimed that there were no suitable conditions for such an isolated action, they were reminded that they had already received a lot of money, gold, diamonds and jewellery from the Russian Bolsheviks for the preparation, and they were interested in knowing what they did with them.
Kučera received a list with names of Czech emissaries who transported the valuables across borders with the task of using them for communist propaganda and bribing agitators and newspaper editors. The article, of course, provoked an affair that all the national and regional newspapers of that time wrote about.

Study objectives. The present study aims to capture the basic features of this case within the reflection on the reports of contemporary Czech newspapers and magazines that dealt with it. Although this is a partial analytical treatise, we see its significance in the concrete documentation of the relationship between the Social Democratic and Communist parties in the period immediately following the establishment of the Communist Party of Czechoslovakia (KSČ) constituted by secession of the so-called Marxist left from the Parent social democracy (May 1921). when the former brothers and sisters became the greatest opponents and rivals; literally becoming mortal political enemies. At the same time, it is a contribution showing the behind-the-scenes practices of the communist movement dissemination, which are not specific to the Czech Republic, and specify some elements in the strategy and tactics of the Russian Bolsheviks in Central Europe, using Communist International (CI) structures on this front. The study's factual basis stems from the research results from 
Russian, Western European and Czech historians in the relevant archives. These findings confirm the veracity of the statements made by both Engelbert Kučera and the financial dependence of $\mathrm{KSC}$ on foreign financial resources, not only in the process of the party's forming, but also in the following years of its existence during the period of the first Czechoslovak Republic (1918 - 1938).

Analysis of sources and literature. As a preliminary point, it should be stated that although not aimed at a synthetic view on this case in the broader context of the differentiation processes taking place within the Czech Social Democratic Party in the early stages of Czechoslovakia, our study actually represents the first attempt of a broader interpretation of the Kučera affair. Of course, authors dealing with the history of KSC until 1989 knew it, but due to this topic's delicacy, unlike other partial problems, they did not process it. It was not desirable to publish the fact that the party was not established in a «natural way» of ideological and opinion differentiation, but to admit that foreign financial means also intended to bribe editors, agitators and officials played a large role in this process. In the period immediately following the «Velvet Revolution» in 1989, Czech historians naturally lost interest in the topic regarding the history of the Communist Party. Only after a «breather» of around ten years can we declare a research return to the topic on the history of the communist movement, which for the most part is associated with the activities with regard to the Institute of Contemporary History of the Czech Republic Academy of Sciences and the personality of Prof. PhDr. Zdeněk Kárník, DrSc. (1931 - 2011). We will only mention a few volumes of the editorial series «Bolševismus, komunismus a radikální socialismus v Československu (Bolshevism, Communism and Radical Socialism in Czechoslovakia)» [Sommer, 2007], which published a number of new contributions by renowned and young researchers critically reacting to works elaborated using Marxist historiography. However, it is interesting that only a minimum of them are devoted to the KSČ genesis issue. The only positive exceptions are the studies of the above-mentioned $\mathrm{Z}$. Kárník, whose interest, however, did not focus on the circumstances of Kučera's case.

Leaving aside various passing references, the Kučera affair has so far been dealt with in a relatively wider form of several lines of information by perhaps only three authors. Poet, literary critic and journalist Antonín Matěj Píša (1902 - 1966); one of the actors in the case and the founder of the Communist Party in Ruthenia, Jan Synek (1880 - 1959); and a researcher at the Slovak Academy of Sciences in Bratislava, Mgr. Juraj Benko, PhD (born 1974). While in the first two cases [Wolker, pp. 458459; Synek, pp. 202-203], the writers took the positions of KSČ and portrayed Kučera as a fraud and a liar - Píša in a commentary on Wolker's prose «Pravda na nároží (Truth at the Corner)» in connection with a critical edition of the work of Jiři Wolker (1900 - 1924), an untimely deceased Czech proletarian poetry representative, and Synek in a memoir article - among other things, based on a study of CI archival material in Moscow on Kučera's text, J. Benko states: «Many parts of his statement, even those concerning money and precious stones provided for CI supporters in the Czech movement, are also confirmed by archival and other sources» [Benko, 2012, p. 329].

Kučera's affair is actually primarily a clash of the press bodies two political parties - Social Democratic and Communist. Newspapers argue with each other and present their vision of the event to readers. Therefore, their press bodies are the main source for our research. With regard to the first case, the main paper in Prague, Právo lidu, its morning and evening editions, and Stráž socialismu from Brno regarding the fact that Kučera then worked in the Moravian capital and published extensively in the paper. We supplement the reports from these two periodicals with a view into the Moravian regional newspapers. Prostějov (Olomouc) newspapers, Nový den and Hlas lidu, became involved in the case due to the fact that one of the emissaries, Jan Synek, transporting valuables from Moscow to Czechoslovakia was the local communist organisation's head during the affair and Prostějov, except for Hodonín, represented one of the labour movement's traditional centres. This range of regional papers is expanded by the Hodonín Slovácký sociální demokrat and the Ostrava Duch času. The Communist Party newspapers naturally took over the positions of Prague's Rudé právo, but Brno's Rovnost was also vehemently involved in the case for similar reasons as the Social Democratic Stráž socialismu. From the regional titles, we chose the Stráž lidu from Prostějov, which had a readership from the whole of Central Moravia, and Svoboda from Kladno, perhaps representing the most belligerent, most radical communist region in Bohemia. We then balance the information and statements of these periodicals with reports from newspapers of those political directions which are not directly interested in the affair and bring more objectivity to it than is the case of the social democratic and communist press. In this respect, news from the Prague's liberal Národní listy and the Brno's Lidové noviny are of the greatest importance. However, we also selectively conducted research in the party press, the rural Venkov, national-socialist České slovo and Socialistická budoucnost, catholic Našinec and Den, as well as in Peroutka's Tribuna, Čas, Moravská orlice, Pozor, the German Prague daily Prager Presse, etc.

Engelbert Kučera's personality is essentially unknown today, regardless of the fact that he is one of a number of figures standing at the onset of the Czech communist movement in Russia alongside Jaroslav Handlír (1888 - 1942) [Lazitch, Drachkovitch, pp. 167168], Alois Muna (1886 - 1943) [Muna, 1919; Lazitch, Drachkovitch, p. 328], Jaroslav Petrlík-Salát (1889 - ?) [Kotyk], František Koza-Permský (1896 - 1942) [Kaplan, J.], Jan Synek [Synek, 1958; Summer, 1965, pp. 60-62], František Beneš (? - 1946) [Beneš], Antonín Bukač [Sommer, 1961, p. 91], Julius Volek-Choráz [Kol., 1989] etc. [D. P. J., pp. 32-33]. Therefore, our fundamental source of information concerning him are his memoirs completed in 1967. They are stored in the Pilsen city archives and in two volumes, they capture his life stories from 1912 - 1967 [AMP]. Interestingly, he mentions the 1921 affair, although, contrary to expectations, he deals with it on a relatively general level, without a more in-depth explanation and 
supplementing and enriching the interpretation intended primarily for the private and non-public spheres with details. Of course, it is a source of a subjective nature containing signs of the apology of his own life story, on the other hand, it is a unique and hardly replaceable source of information regarding his activities and opinions. We approach it critically.

Research results. We divided our own interpretation into two thematic blocks, whereby the first brings basic data from Kučera's biography and the second evokes his own affair through the analysis of the daily press.

Who was Engelbert Kučera (*October $30^{\text {th }}, 1889$ Rájec u Blanska, †November 21 ${ }^{\text {st }}, 1967$ Pilsen), who lived a rich, quite dramatic life with various twists and turns? In front of us lies the faith of a man coming from a socially weak family background (his father worked as a coachman on a large farm, who along with his wife, took care of the household, and had 11 children), and due to his hard work and tenacity, worked first as a trained electromechanical engineer but after the World War I, after leaving Brno to live permanently with his family in Pilsen, he had worked his way up to the position of senior official of the District Sickness Insurance Company and an expert in the field of social care. Although, from a formal viewpoint he did not have a higher education degree (two-year vocational school), this shortcoming was compensated by his natural intelligence and desire for self-education, which, throughout his life, he fulfilled with enthusiastic, fast and continuous reading of books, newspapers and magazines and interest in many disciplines (political science, history, literature, astronomy, radiotelegraphy, astronautics, military), cultural and sporting events, while applying the acquired knowledge through numerous public lectures, but mainly as a publicist. Journalism had literally become his lifelong passion. At home, but also during his stay in Soviet Russia, he wrote hundreds of articles and series for newspapers (especially Pilsen's social democratic press Nová doba and Týden), but was also translating fiction, short stories and novels from Russian into Czech, including Petruševsky's prose Fryné [Petruševskij]. For several years, as an externalist in the above-mentioned Pilsen papers, he led a socio-political column where he informed readers about the claims and rights of insured people, explaining the sickness insurance scheme and searched for the history of health insurance. He also sent his articles to the Prague magazine «Důchodce a pojištěnec» and had his «watch» there. He was very proud of this activity, as he saw it as an activity «for the benefit of workers». When listing Kučera's interests, we cannot fail to mention his love of classical music, he particularly loved Opera Arias, and he also had another passion, this time for bowling, a sport that was going through a boom in Bohemia in the 1940s. Especially during the period after World War II, he became involved in the atheistic and cremation movement as a functionary at regional level in the Union of Citizens without Religion and then in the Association of Crematorium and the Association of Friends of Cremation.

However, Engelbert Kučera is most aptly characterised by the nickname homo politics. He had excellent predispositions for involvement in political and public life thanks to his organisational and rhetorical talent. He was able to mutually connect both of these dispositions with circumspect demeanour. Therefore, he enjoyed natural authority and was elected to leadership positions in organisations. From the age of 18, he was a Social Democratic Party member, soon followed by joining the trade union and workers' sports movement. Hence, before the war, as a twenty-five-year-old young man, he had already worked in Hodonín in South Moravia not only as a local secretary but also as a Regional Social Democracy Committee member and a respected functionary of the Workers' Sport Union at regional level.

World War I significantly affected Kučera's life. He was drafted into the Austro-Hungarian army and sent to the Eastern front. However, after three months, in November 1914, he deserted into Russian captivity and ended up in a prison camp near the town of Usman in the Tambov Governorate. Due to the fact that he spoke Russian language quite well, he came in useful as an interpreter and was simultaneously able to establish contacts with the local environment. In April 1915 he obtained a job as a mechanic at the municipal power plant in Usman and later in Tambov, where he became involved in political affairs in August 1917 by joining the Russian Communist Party (Bolsheviks) and, after the October Revolution, he became the chairman of a local communist organisation established by Czech and Slovak prisoners. The prisoners also sent him to Moscow as a delegate to the founding congress of the Communist Party of Czechoslovakia in Ruthenia (May 25-27, 1918) [D. P. J., 1925; Veselý, pp. 103-108; Pichlík, 1991, pp. 416-420; Kárník, 1966, p. 19; Klevanskij, pp. 134-140; Kalvoda, pp. 306-308]. Ideologically, he moved to the position of Bolshevism and became a professional political worker in the Governate's Military Commissariat as the agitation department chairman. In August 1918, he was appointed as a district military commissioner in Usman and, from June 1919 to May 1920, he served as the KSR district committee chairman (b) in Marshansk. Wanting to return to his homeland, he went through a preparatory course for emissaries in Moscow and left for Czechoslovakia to work in illegal communist structures and prepare the ground for a revolutionary coup. He became a member of the illegal leadership of the Marxist left party and officially worked as the secretary of the legal Marxist left party and the Labour Council secretary in Brno [AMP, E. Kučera, životopis (AMP, E. Kučera, biography), 1, pp. 3-29]. With regard to himself, he claimed: «I was an ideologically based communist, ready to sacrifice my life for an idea» [Prodali vlastní svědomí a příslušníky své strany (They sold their own conscience and members of their party), Právo lidu, 1921, v. 30, no. 160, July 10, p. 3].

The year 1921 can be described as a key period in Kučera's political career. At the beginning, he represented one of the prominent figures of the communist wing in Czech social democracy, mainly applying in its illegal structures. This hypothesis is supported by the fact that the party's illegal committee instructed him to report to the Communist International 
in Moscow on the outcome of the December general strike in Czechoslovakia in 1920, which, according to Moscow's intentions, was to result in a Bolshevik coup and the Communist takeover [Olivová, 2000, pp. 121122; Olivová, Kvaček, 1967, pp. 91-94; Kárník, 1996, p. 493; Vrbata, pp. 330-332; Kocman, pp. 194-196; Burian]. However, according to the official interpretation it was Kučera's trip to Soviet Russia in early 1921 that was the turning point in his radical pro-communist thinking. Negotiations with Béla Kun and the knowledge he gained during his stay in Moscow and in the Tambov Governate allegedly led him to leave the communist movement. The Bolshevik again became a social democrat. In the communist movement's terminology, he took the position of a centrist. After returning to Czechoslovakia on May $9^{\text {th }}, 1921$, he resigned from all positions and, in July 1921, published an article in the Prague's main daily in relation to the Social Democratic Party, Právo lidu, which provoked an affair in the press, whereby we devote our contribution to the reaction. Kučera's justification for leaving the communist movement was not complete in the initial phase of the affair and he gradually expanded his arguments. He was irritated by the fact that in the Czech communist movement's leadership there were people with character deficits, bad reputations, or even delicts of a criminal nature [Sršatá pokřrivená Rovnost (Vitriolic and Distorted Rovnost), Stráž socialismu, 1921, v. 2, no. 112, July 12, p. 5; K analysi Kučerova odhalení (On the Analysis of Kučera's Revelation), Duch času, 1921, v. 23, no. 195, July 27, pp. 2-3]. He did not agree with the Communist Party accepting all of the CI's 21 conditions. He was disgusted by the fact that the material aid received by the Communists from Soviet Russia was being misused by some individuals to their advantage. In one part he writes: «Once it is revealed for what and where a large part of Russian gold, diamonds and money sent for propaganda was used, then, even the last Czech worker must turn away from them in disgust» [Rovnost zase nadává (Rovnost curses again), Stráž socialismu, 1921, v. 2 , no. 115 , July $15^{\text {th }}$, p. 4]. According to the communist Stráž lidu, Kučera was also influenced by the attitudes of his partner and future wife from Tambov. The outbreak of the affair occurred soon after he managed to transport her with his child to Czechoslovakia [E. Kučera mluví.... (Kučera speaks...), Stráž lidu, 1921, v. 3, no. 110, October $21^{\text {st }}$, p. 2].

E. Kučera remained a member of the Social Democratic Party until 1948, when the party merged with (was absorbed by) the Communist Party [Malír. Marek, 2, p. 1171; Fajmon, Balík, Hloušková, p. 33]. However, he continued working in it basically as an ordinary member refusing to accept higher positions. With his attitudes, he belonged to its left wing and his colleagues jokingly called him a «Bolshevik» as his opinion on the Pilsen Social Democrats running this industrial centre in the interwar period was radically critical. On May $9^{\text {th }}$, 1945, he received an offer to join the party from the Regional Committee of the Communist Party in Pilsen. The Communists wanted to take advantage of his organisational, rhetorical and journalistic predispositions, as well as the fact that he had worked in the resistance movement during the Nazi occupation of Czech lands and promised to secure a promising career. Kučera rejected the offer despite the threat that during the negotiations he might regret not signing the application. The threat came true after the communist February coup in 1948 [Hanzlík; Kaplan, K.; Veber], when he was fired from his job and found a solution in retiring on the grounds of invalidity. Paradoxically, it was at a time when, as a follower of the idea of the labour movement unity, he welcomed the fusion of social democracy with the Communist Party, filing an application to the Communist Party and was nominated to review (merging) committees managing social democrats during their transfer to the Communist Party. He was quite personally and strongly offended by the fact that the Communist Party did not reciprocate his interest in joining the party.

Kučera's memoirs show that in the final period of his life (in the 1950s and 1960s) he was relatively strongly influenced by communist ideology and propaganda and identified with the idea of building socialism in Czechoslovakia and in the world. Without much misjudgement, we can call him an advocate of Stalinism and communist totalitarianism. For example, he accepted the political processes of the 1950s and during the Cold War defended the Soviet Union's policy against «American soldiers and imperialist aggression», fighting against the dissemination of socialism in the world. On the other hand, his identification with the regime was not absolute, and in many circumstances, he judged the reality critically. As a result of deviating from Marxism principles, he saw the causes of errors, shortcomings and misunderstandings. He believed they arose due to deficits in the educational work of the KSČ. The context of Kučera's conclusions is an unspoken call to revive those values which, in his opinion, were inherent to social democracy and the traditional socialist labour movement [AMP, E. Kučera, životopis (AMP, E. Kučera, biography), 2, pp. 27-86].

The second part of the article is devoted to the reflection of the Kučera's affair from 1921 from the daily press. Due to the fact that the newspapers mostly took over, or paraphrased the facts printed in periodicals published in the centre, the views of three opinion currents are relevant for the interpretation - the social democratic, communist and the one of party newspapers and entities that were not directly involved in the case. We summarise the information with regard to the paper's scope.

The information concerning his personal conversation with CI representative Béla Kun in the spring of 1921 in Moscow, where he was illegally sent together with the Prague functionary of the Marxist left wing and from 1920 the editor of Rudé Právo, Oldřich Berger (pseudonym Otto Brener, 1891 - 1956) [Tomeš, 2005, pp. 33-34; Tomeš, 2006], may be determinate as probably the most serious statement by Kučera (1886 1938) [Borsani; Zubov, pp. 623-624; Lazitch, Drachkovitch, pp. 239-241]. In it, Kun rejected the idea of Czechoslovak communists presented and defended by Bohumír Šmeral (1880-1941) [Galandauer; Clergy; Za sovětské démanty a zlato (For Soviet Diamonds and Gold), Hlas lidu, 1921, v. 36, no. 78, July $14^{\text {th }}$, pp. 1-2] on the need to coordinate proletarian revolutions in 
Central Europe and to only use them in smaller countries when the Communists can ground it on a victorious proletarian revolution in a big country. He called for immediate action to spread the revolution, which must not stop even before an obstacle in the form of nation states. The interest of the world proletariat is decisive. Czechoslovakia is an artificial and temporary product of World War II, whose current borders are still unstable, and the final word in this matter has not yet been spoken. It must disappear from the map of Europe [Nový důkaz proti komunistům (New Evidence Against the Communists), Stráž socialismu, 1921, v. 2, no. 118, July $19^{\text {th }}$, p. 2].

Kun's words outraged both the socialists and the entire Czech population. His words were not only seen as an attack on the restoration of Czech statehood destroyed after 1526 by incorporating the Czech Crown into the Habsburg monarchy, but also on the Czech nation, which, by establishing the republic in 1918, completed the emancipation and modernisation processes taking place since the end of the $18^{\text {th }}$ century and national selfreflection helped it reach the level of advanced European ethnic groups [Kořalka]. Society had difficulties coping with the policies of its southern neighbour, Hungary. After the collapse of the monarchy and the creation of successor states, he did not want to accept the loss of Slovakia and dreamed of the restoration of Great Hungary. The memory of the recent (1919) invasion of the Bolshevik Hungarian Red Army into Slovakia and the bloody clashes and battles with the Czechoslovak army still felt alive, and the Hungarian irredentism [Tomášek] were constantly «reopening» this painful and lively wound. Therefore, the Czech socialist press described Kun as its exponent, a Hungarian adventurer and chauvinist, «a brute and villain of the Hungarian proletariat» [Béla Kun na válečné stopě (Béla Kun on the war track), Stráž socialismu, 1921, v. 2, no. 150, August $26^{\text {th }}$, p. 2], covering the defence of Hungarian national interests with his function in the CI. "The Hungarian Bela Kun did not give up hope that the break-up of Czechoslovakia could fulfil the dream of Hungarian chauvinists to reunite Slovakia with the Hungarian Empire. They are crazy plans of cynical adventurers') [Ke schůzím E. Kučery (To the meetings of E. Kučera), Novýden, 1921, v. 3, no. 82, October $15^{\text {th }}$, p. 1].

Kučera's view into the party's internal affairs was very unpleasant, even directly discrediting, for the communists. He published the fact that the communist movement in Czech lands is in fact run from two centres. The first one is the legal, well-known and elected structures that represent the KSC before the public and engage in activities in the political system. However, according to the CI regulation, in addition to them there is also the illegal leadership of the party selected in Moscow and controlled from there, composed of trusted and loyal people who are also under the strict control of the emissaries appointed by the CI, in this case Mátyás Rákosi (1892 - 1971) and Gyula Alpari (1882 - 1944), who were connected to Kun. Its personnel form is secret and is not known even to a wider circle of party elites. However, the importance of this body in the party is paramount, because it is the organ that de facto manages it and decides on important matters. The elected party bodies provide a background that covers the underground structures and their activities. The party's illegal leadership activities were bailed out from Moscow's financial resources, the fact of which the official authorities do not even know [Kulisa mluví, kulisa dělá zed' (Background speaks, background makes a wall), Večerník Práva lidu, 1921, v. 10 (30), no. 164, July 23th, p. 1; Gold and Diamonds, Nový den, 1921, v. 3, no. 61, July $30^{\text {th }}$, p. 3].

The explosiveness of Kučera's statement, based on autopsy, as he himself worked in illegal and official party structures, not only consisted in revealing the organisation's management mechanism, but above all in pointing out the suspicious character traits of some influential individuals occurring at these levels of party politics and the consequences resulting from it. In Moscow, Kučera obtained a list of Czech communists who, on their return to Czechoslovakia after captivity or from various trips to Soviet Russia, were carrying various valuables (gold, diamonds, brilliants, rings, gold watches) and money (Russian roubles, English pounds, German marks) intended to bail out the communist movement's requirements for the («technical preparation of the revolution»), primarily to develop propaganda, which also included bribing secretaries, newspaper editors and people usable for this activity [Dokument komunistické politické zvrhlosti (Document on Communist Political Degeneracy), Hlas lidu, 1921, v. 36, no. 77 , July $12^{\text {th }}$, p. 2]. It turned out that this material aid did not always reach its destination, and some emissaries misused it and used it for their personal use. This case included the names of today's «anonymous» former Red Army soldiers, as well as prominent figures such as Jan Synek, Alois Muna, Miloš Vaněk, Antonín Zápotocký, Jaroslav Petrlík-Salát, Břetislav Hůla, Jaroslav Handlír, JUDr. Václav Houser, etc. Kučera himself, but especially the socialist press, evaluated, generalised and used these findings for sharp attacks on the communist movement. His conclusions were clear: the communist movement in Czech lands fell into the hands of adventurers, gold and diamond-bribed agents of provocateurs who seemingly serve the workers' interests, but are in fact under the command of Béla Kun, whose only goal is to subvert Masaryk's Republic and plunge the working class and the whole Czechoslovak nation into a new bondage and slavery [Strach před Kučerou (Afraid of Kučera), Hlas lidu, 1921, v. 36, no. 81 , July $21^{\text {st }}$, p. 3]. In the higher reaches of the Communist Party, there are people who are corruptible and characterless, they are not driven forward by an idea, but by a desire for profit [Ke Kučerově odhalení (To Kučera's Revelation), Večerník Práva lidu, 1921, v. 10, no. 163, July $22^{\text {nd }}$, p. 2].

The Czech communists were also uncomfortable with Kučera's warning against imitating the Russian model. He appreciated the October Revolution. In his opinion, it had created a deep groove in the history of the Russian nation, influencing conditions in Central and Western Europe and, at least in the initial phase, it brought many good things that the Western European proletariat will learn from. However, it must not become something that we worship, as some communists do [Ke schůzím E. Kučery (To the meetings of E. Kučera), Nový den, 1921, v. 3, no. 82, October $15^{\text {th }}$, p. 1]. Kučera did 
not hide the fact that people must be told the truth, and not told fairy tales about Soviet Russia's real situation. People like Šmeral, Olbracht or Doležal saw Potemkin villages. They are «faithful communists» who could only enter the country as owners of several ID documents, stamps and certificates of their orthodoxy. Kučera not only went against this stream in the press, but also using speeches at several meetings (e.g., Prague, Ostrava, Česká Třebová, Tišnov, Olomouc, Prostějov, Staré Město nad Metují, Ústí nad Labem). His speeches were accompanied by tumultuous confrontations between the Social Democrats and the Communists and polemics in the press. Among other things, in Olomouc, Kučera declared: The hoped-for communist paradise is a deceit and the one who defends it is a political windbag [Bechyně, Janík, Kučera v Olomouci (Bechyně, Janík, Kučera in Olomouc), Nový den, 1921, v. 3, no. 83, October $19^{\text {th }}$, pp. 3-4]. In Ostrava, he was physically attacked by the communists led by Dr. Emanuel Vajtauer (1892 - ?) [Čelovský] and he felt his life was threatened [Zdrcující soud ostravského dělnictva nad komunistickými násilníky (Crushing judgement of Ostrava workers over communist criminals), Duch času, 1921, v. 23, no. 206, August $2^{\text {nd }}$, pp. 1-2].

We will now look at the affair from the communist press viewpoint. Its reaction was essentially twofold. On the one hand, these articles emphasised that Kučera's accusations were serious and reflected in relations between the Communist Party and the Social Democratic Party; therefore, the case was also on the agenda of the Communist Party's Central Committee on July $21^{\text {st }}, 1921$ [Prohlášení (Declaration), Rudé právo, 1921, v. 2, no. 171 , July $23^{\text {rd }}$, p. 1]. On the other hand, the Communist Party press bodies tried to downplay the case: «It would be undignified to answer his lies» [Miliony z Ruska (Millions from Russia), Stráž lidu, 1921, v. 2, no. 78, July $16^{\text {th }}$, p. 2]. The press began to compete in the originality of condemning Kučera's statements. They were not only false, but also silly, foolish, and bold, fairy tales from the Thousand and One Nights, inside scoop of the slow news days, canard, but also evidence of political misery and crime, an example of worker betrayal, clever slander, evidence of a campaign against the Communist Party and a smiling affair. The communist press was insulting the author with unscrupulous insults and nicknames such as a grotesque figurine, a lying individual, an empty nobody, a political hustler with great style, disgraceful creature, talkative gossiper, liar, villain and blackmailer, rogue, scoundrel, provocateur, opportunist, fraudster, rake, sloppy, exemplary of human degeneracy, political snooper, right-wing rarity, working class traitor, «brilliant king», etc. The communist press reaction to Kučera's revelation shows that the startled Communist Party did not intend to deal with the substance of the accusations, but rather built its apology on discrediting the writer and his background and transfer the essence of the affair to the level of morality.

The Communist Party's press bodies paid most of their attention to finding the motives that led Kučera to appear in public in the opponent newspapers, i.e. Social Democratic party. They concluded that money was in fact behind everything, Kučera's private interests and his distorted character. When he returned from a spring trip to Soviet Russia in 1921, incidentally bailed out from the party's resources, and from where he had brought his wife and child, he urgently needed money. Firstly, to furnish their new home, but also to ensure a high standard of living. His wife came from a «bourgeois family» and was accustomed to a large income and a lavish lifestyle. That is why Kučera offered the party's leadership the sale of documents concerning the transport of gold, jewellery and money by Czech emissaries from Soviet Russia to Czechoslovakia. He demanded 150,000 crowns, promising to remain silent about everything he learned about the Czech communists in Moscow. However, when the people from the party leadership rejected Kučera's blackmailing proposal, as well as the once traitor Šviha did [Hůla; Marek], he gave the compromising materials to the Social Democracy. It was no accident, because it was the Social Democratic party, with its influential leaders, who were members in the state administration, where he sought rescue and help. He was threatened with imprisonment for bigamy - he had two lawful wives - he did not divorce from his first wife living in Hodonín and married again for the second time in Russia [O těch pěti milionech (On the Five Million), Red Law, 1921, v. 2, no. 163, July $14^{\text {th }}$, p. 7; Kdo je Engelbert Kučera? (Who is Engelbert Kučera?), Rudé právo, 1921 , v. 2 , no. 167 , July $19^{\text {th }}$, p. 1]. «This is the real background to the whole revelation of Engelbert Kučera, the blackmailer and great-style impostor» [Engelbert Kučera, Rovnost, 1921, v. 37, no. 190, July $11^{\text {th }}$, p. 3]. «A man who tried blackmail for stolen documents - according to his own confession - asking for 150,000 crowns and was kicked out, suddenly makes himself extraordinary, a person honest about the fate of the working class, rightfully belongs to the society he joined» [Pan Engelbert Kučera (Mr. Engelbert Kučera), Rovnost, 1921 , v. 37 , no. 146 , May $28^{\text {th }}$, p. 5]. He is not only a blackmailer, but also a traitor to the working classes. «He damns everything he himself preached, and indirectly confesses that he deliberately deceived and lied the anti-supporters of the Communist Party» [Pan Engelbert Kučera (Mr. Engelbert Kučera), Rovnost, 1921 , v. 37, no. 146 , May $28^{\text {th }}$, p. 5]. «For decent people, there can be no doubt that a man, who detaches himself from his own party today and runs to the enemy's party tomorrow like a talkative gossiper, to curse what he himself did until yesterday and 'gossiping' about people, which he used to brown-nose, is a disgraceful creature» [Časové poznámky (Time Notes), Rovnost, 1921, v. 37, no. 195 , July 16, p. 5].

Through personal attacks on Kučera and attempts to discredit him, the communist press diverted attention from the very essence of the case. Therefore, it manipulated with a fake Kučera letter, which was to convict the writer of blackmailing [Podvodník a vyděrač Kučera (The Impostor and Blackmailer Kučera), Rovnost, 1921, v. 37, no. 195 , July $16^{\text {th }}$, pp. 1-2]. The press questioned some facts from Kučera's life in Russia [Richtr]. The campaign against him not only included the statement of B. Kun [Projev soudruha Bely Kuna. «Odhalení» (Speech by Comrade Bela Kun. «Revelation»), Rovnost, 1921, v. 37, no. 234, Aug. $25^{\text {th }}$, p. 1; Rázný projev Bely Kuna proti lživé kampani Kučerově (Bela Kun's vigorous speech against Kučera's 
false campaign), Rudé právo, 1921, v. 2, no. 199, August $26^{\text {th }}$, p. 4], but also the People's Commissar for Foreign Affairs Georgiy Vasilyevich Chicherin (1872 - 1936) [Poselství Čičerinovo Francii a Československá republika (Chicherin's Message to France and the Czechoslovak Republic), Rovnost, 1921, v. 37, no. 227, August $18^{\text {th }}$, p. 2]. However, the opinions of these officials did not respond to what Kučera actually said. The press Rovnost tried to persuade him to file a criminal accusation for defamation, and when he refused, it presented his attitude as evidence of lying. It urged him to commit suicide by shooting, because this is what every honest person is said to do in case he is convicted of lies and fraud.

The second characteristic feature of communist journalism in the Kučera's affair was the reference to the inspirer of the case. The writers of the articles were convinced that the Social Democratic Party's right-wing leadership was behind everything. The Rovnost press did not spare its former colleague: "We do not consider the Kučera case any small feat, because the whole Czechoslovak Social Democratic party is standing fully behind him today. A political party that will even become a part of this state's government in a few weeks and whose leading leaders, standing next to the imposter Kučera, will hold the republic's reins in their hands. It so happened that Kučera's affair is not his own personal affair. The whole Social Democratic Party has taken it as its own, because it is the one that is still trying to get the capital out of it, using it against the Communists». It even put up posters with Kučera's false statements, and it puts the downright liar and the mendacious profiteer on its front shield. It is a moral trigger of the worst kind created by the «proverbial angry hate of the Communists». The party leadership is capable of any wickedness. We are witnessing degeneracy that has never been seen in our public life. «But it's not uncommon for treacherous characters» [Ještě nežaloval! (He hasn't told tales yet!), Rovnost, 1921, v. 37, no. 230, August $21^{\text {st }}$, p. 2]. Even in this case, article writers competed in the originality of condemning the Social Democratic party's behaviour. For example, in Rudé právo we can read the following words: The most terrible thing about the whole matter is that Kučera is «in the company of Němec, Tusar, Bechyně, Soukup murderers of Czech working class». "Today, social democracy represents the disease of the proletariat. It is a working-class scab» [Jak píše dělník o Engelbertu Kučerovi a Františku Benešovi (How a Worker Writes About Engelbert Kučera and František Beneš), Rudé právo, 1921 , v. 2 , no. 215 , September $14^{\text {th }}$, p. 5]. «If the political dynasty from Lidový dům (People's House) and the Castle thinks that they will supress the communist movement with such gossip, then it shows that it has no idea of the great historical tides that washes the communist party from the sludge that stuck to it here and there, and which the social patriots carefully collect and display in public...» [Probuzené svědomí (Awakened Conscience), Rudé právo, 1921, v. 2, no. 258, November $4^{\text {th }}$, p. 7].

The issue concerning the import and use of gold, valuables and money remained in the communist press virtually without comment and was resolved by a statement about fabrications of «whining nationalists» who «galvanise the corpse of a rotten Social Democratic party» [Podvodník a vyděrač Kučera (The Impostor and Blackmailer Kučera), Rovnost, 1921, v. 37, no. 195, July $16^{\text {th }}$, p. 1$]$.

The third part of our explanation of the Kučera's affair reflects the attitudes of the newspapers of political parties and entities, which we have identified as not materially involved in the case. They basically acted as a mentor informing their readers about the crisis in the Social Democratic party, or about the character of the Communist party, and reflected on the significance of the event, or sought lessons to learn from it.

The attempt to summarise this whole journalistic stream offers the following conclusions. All the newspapers we reviewed agreed that the information published was serious and shocking. Although in substance, they do not bring something completely new that the public would detect a hint for the first time, but their surprise lies in the fact that 1) they openly inform about the existence of a plan to destroy the Czechoslovak Republic and 2) the reaction of the Communist Party, or its press bodies is not adequate to the situation. Instead of explaining, the press deviates from the essence of the matter, and instead of refuting the facts, they plot personal attacks and move to ridicule people and downplay the case. By publishing other cases where emissaries transported gold, jewellery and money from Soviet Russia to Czechoslovakia, as well as other states to bail out the communist movement's requirements, the press confirms the veracity of Kučera's claims on these issues. «The accusations so serious such as the statement substantiated by certain circumstances, statements and figures that the leaders of the Czech Communist Party are in paid, foreign services, in the service of politics that does not hide its intention to destroy the Czechoslovak Republic when the interests of the internationals so require and, in particular, how Bela Kun strives to do so, are not overcome by jokes and they are not quite as clumsy as the Rudé právo tries to depict them to get out of troubles» [Československý stát. Čeští komunisté v cizích službách (Czechoslovak State. Czech Communists in Foreign Services), Národní listy, 1921, v. 61 , no. 189 , July $12^{\text {th }}$, p. 1]. Authors of the articles see Kučera as a communist who, under the pressure of personal knowledge, awoke, sobered up from the thrill of communistic ideas, they emphasise his patriotic feeling that prefers the nation to internationalism, and generally sympathise with him. The authors believe the allegations of trying to lure money from the Marxist left for handing over compromising materials obtained in Moscow are false. They wonder how it is possible that the Communists in Czechoslovakia are given so much space for their subversive activities and that the state administration has not intervened against them yet. Furthermore, it is sad that their victim is an honest Czech worker who has no idea about their games and the villainous greedy people make him a slave of foreign interests and a traitor of Czech autonomy and independence, a murderer of social progress and prosperity. The fact that there are Czechs selling the Czechoslovak state and nation is not surprising - outcasts and criminals are everywhere. But that there were people 
around the press Rudé právo who defended them and supported them in their treacherous actions, «this is such a terrible thing that never had and will never have a match». The Communist Party is «an organisation of bought destroyers of their own state» [NA Praha, Organisace podlosti (NA Prague, an Organisation of Wickedness), Národni demokracie, July $\left.14^{\text {th }}, 1921\right]$. The significance of the Kučera's affair lies in the fact that perhaps will finally open the eyes of the masses of people who were seduced by the Communists.

Research conclusions. We consider the E. Kučera's affair, caused by his journalistic speech in the Právo lidu newspapers in the summer of 1921, to be an episodic event that fits into the context of the tense relations between the Czech Social Democrats and the Communists at the time. The Social Democratic Party leadership, which was the winner of the April parliamentary elections in 1920 with over $25 \%$ of the vote [Kárník, 2000, pp. 123-128], realised that with the Communist Party's establishment, the party was losing a substantial part of its membership base and political positions, and, in the future, the party also had to count with a limited party electorate. Against this threat, the party adopted a whole series of measures, including a systematic anti-communist press campaign in party newspapers and magazines. There can be no doubt that the propaganda potential of Kučera's behaviour in the spring of 1921 after his return from Soviet Russia was to be used to its advantage. The party provided support to Kučera, who had lifelong oscillations between the visions of socialism and communism, and gave him space for self-presentation, from which the party itself benefited. In this respect, he was the «man of the moment», or a «comet», whose glow quickly faded. On the other hand, we do not intend to downplay this character. The information contained in our article complements the historiography dealing with the history of the Communist Party in Ruthenia, showing that he belonged to the group of its founders and protagonists. At the same time, we see the whole life story of Engelbert Kučera in the spirit of Hannah Arendt's conception as a struggle for the right of man to private political freedom. For his political and public involvement, he chose such activities that he would consider as the optimal share in the form of public affairs, which allowed him to make decisions based on his own moral criterion formed by the social environment in which he lived. The spotty success of his efforts depended on the democratic and totalitarian regimes of the $20^{\text {th }}$ century interfering and limiting his political demeanour.

\section{References}

Adibekov, G. M. (ed.), 2004. Politbjuro CK RKP(b) i Komintern 1919 - 1943. Dokumenty, Moskva: Rossijskaja političeskaja encyklopedija, $608 \mathrm{~s}$.

AMP, f. Engelbert Kučera (1912 - 1967), k. 406/7, Životopis, 1. díl, od narození do konce protektorátu; 2. díl, od května 1945.

Bechyně, Janík, Kučera v Olomouci. Zdrcující porážka komunistů, Nový den, 1921, r. 3, č. 83, 19. 10., s. 3-4.

Béla Kun na válečné stopě, Stráž socialismu, 1921, r. 2, č. 150, 26. 8., s. 2.

Bela Kun př́telem Československé republiky, Stráž socialismu, 1921, r. 2, č. 132, 4. 8., s. 5.

Beneš, F., 1920. Agenti-provokatéři v dělnickém hnutí a v republice: řeč redaktora Fr. Beneše před soudem a různé svědecké výpovédi v jeho soudním sportu s československými komunisty, Moravská Ostrava: Duch času, $30 \mathrm{~s}$.

Benko, J., 2012. Bol'ševizmus: medzi Východom a Západom (1900 - 1920), Bratislava: Historický ústav SAV v Prodama, 218 s.

Benko, J., 2007. K možnostiam, metódam a prostriedkom činnosti Kominterny v strednej Európe v prvých rokoch existencie (1919 - 1922): Na hranici legality a ilegality. Radikálny socializmus a komunizmus na Slovensku (1918 - 1989): spoločnost' medzi demokraciou a totalitou, Banská Bystrica: Katedra historie fakulty humanitných vied Univerzity Mateja Bela, Historický ústav Slovenskei akadémie vied, s. 11-25.

Benko, J., 2012. Sovietske Rusko, Kominterna a financovanie komunistického hnutia v strednej Európe 1917 - 1922. Český a slovenský komunismus $(1921$ - 2011), Praha: Ústav pro soudobé dějiny AV ČR, Ústav pro studium totalitních režimů, s. 317-332.

Borsanyi, G, 1993. The life of a Communist revolutionary, Béla Kun, Boulder - New York: Columbia University Press, 520 p.

Burian, E., 1921. „Komunistický puč“ ve světle pravdy, Rovnost, r. 37, č. 6, 7. 1., s. 1.

Cizí peníze a socialistická frakce, Našinec, 1921, r. 57, č. 58, 14. 7., s. 4.

Časové poznámky, Rovnost, 1921, r. 37, č. 195, 16. 7., s. 5.

Čelovský, B., 2002. Strážce nové Evropy. Prapodivná kariéra novináře Emanuela Vajtauera. Šenov u Ostravy: Tilia, 204 s.

Československá republika musí zmizet, Pozor, 1921, r. 28, č. 189, 12. 7., s. 2.

Československo musí zmizet z mapy Evropy!, Rudé právo, 1921, r. 2, č. 167, 19. 7., s. 3.

Československý stát. Čeští komunisté v cizích službách, Národni listy, 1921, r. 61, č. 189, 12. 7., s. 1.

Čeští komunisté v cizím žoldu, Národni listy (večerní vydání), 1921, r. 61, č. 188, 11. 7., s. 1-2.

D. P. J., 1925. Kdo a jak byl proti nám, Česká ročenka 2, s. 26-43.

Dokument komunistické politické zvrhlosti, Hlas lidu, 1921, v. 36, no. 77, 12. 7., s. 2.

Drabkin, J. S., (ed.), 1998. Komintern i ideja mirovoj pevoljucii. Dokumenty, Moskva: Nauka, 949 s.

Engelbert Kučera, Rovnost, 1921, r. 37, č. 190, 11. 7., s. 3.

E. Kučera mluví..., Stráž lidu, 1921, r. 3, č. 110, 21. 10., s. 2-3.

Engelbert Kučera mluví, Lidové noviny, 1921, r. 29, č. 366, 24. 7., s. 2.

Engelberte Kučero, žaluj nás, Socialistická Budoucnost, 1921, r. 19, č. 165, 17. 7., s. 2.

Fajmon, H., Balík, S., Hloušková, K. (eds.), 2006. Dusivé objetí. Historické a politologické pohledy na spolupráci sociálních demokratů a komunistù, Brno: Centrum pro studium demokracie a kultury, $151 \mathrm{~s}$.

Firsov, F. I., 2007. Sekretnyje kody istorii Kominterna, Moskva: AIRO, 576 s.

Galandauer, J., 1986. Bohumir Šmeral. 1914 - 1941, Praha: Svoboda, 513 s.

Hanzlík, F., 1997. Únor 1948. Výsledek nerovného zápasu, Praha: Prewon, $255 \mathrm{~s}$

Hůla, B., Když se probudí svědomí, Rudé právo, 1921, r. 2, č. 163, 14. 7., s. 1-2.

Jak píše dělník o Engelbertu Kučerovi a Františku Benešovi, Rudé právo, 1921, r. 2, č. 215, 14. 9., s. 5.

Ještě nežaloval! Rovnost, 1921, r. 37, č. 230, 21. 8., s. 2. 
K analysi Kučerova odhalení, Duch času, 1921, r. 23, č. 195, 27. 7., s. 2-3.

Kalvoda, J., 1998. Genese Československa, Praha: Panevropa, 607 s.

Kaplan, J., 1986. Život Františka Kozy Permského (1896 - 1942), Hradec Králové: Kruh, 91 s.

Kaplan, K., 1997. Pět kapitol o únoru, Brno: Doplněk, 556 s.

Kárník, Z., 2000. České země v ére Prvni republiky, 1. Vznik, budováni a zlatá léta republiky (1918 - 1929). Praha: Libri, 571 s.

Kárník, Z., 1966. První pokusy o založení komunistické strany v Čechách, Praha: Academia, 67 s.

Kárník, Z., 1996. Socialisté na rozcestí. Habsburk, Masaryk nebo Šmeral. 2. vyd. Praha: Karolinum, 554 s.

Kdo je Engelbert Kučera?, Rudé právo, 1921, r. 2, č. 167, 19. 7., s. 1.

Kdo jsou podvodníci?, Právo lidu, 1921, r. 30, č. 170, 22. 7., s. 2.

Ke Kučerově odhalení, Večerník Práva lidu, 1921, r. 10, č. 163, 22. 7., s. 2.

Ke schůzím E. Kučery, Nový den, 1921, r. 3, č. 82, 15. 10., s. 1.

Klevanskij, A. Ch., 1973. Českoslovenští internacionalisté a legionářský sbor v Rusku, Praha: Horizont, $250 \mathrm{~s}$.

Klír, M., 1964, 1965. Úloha B. Šmerala při vypracování stranicko-taktické orientace KSČ, Přispěvky k dějinám KSČ, r. 4, č. 5, s. $651-684 ;$ r. 5, č. 1 , s. 3-40.

Kocman, A., Pletka, V., Radimský, J., Trantírek, M., Urbánková, L. (eds.), 1969. Boj o směr vývoje československého státu, 2. červenec 1919-květen 1921, sv. 2. Praha: Nakladatelství Československé akademie věd, 404 s.

Kol., 1989. Julius Volek-Choráz. Sborník projevů z ideologické konference OV KSČ v Prostějově konané dne 16. června 1988, Prostějov: Dům politické výchovy OV KSČ, 59 s.

Komunistické nesnáze. Další odhalení zatajena, Tribuna, 1921, r. 3, č. 165, 15. 7., s. 3.

Kořalka, J., 1996. Češi v habsburské ř́iši a v Evropě 1815 - 1914. Sociálněhistorické souvislosti vytváření novodobého národa a národnostni otázky v českých zemích, Praha: Argo, $354 \mathrm{~s}$.

Kotyk, J., 2018. Anarchokomunista Jaroslav Petrlík - Salát, pozapomenutý pardubický rodák - ke 100. výročí bolševické revoluce, Zprávy Klubu př́tel Pardubicka Pardubice 53, č. 1-2, s. 61-63.

Kučera, E., 1921. III. internacionála a Československá republika, Stráž socialismu, r. 2, č. 153, 30. 8., s. 1-2.

Kučerova odhalení, Pozor, 1921, r. 28, č. 193, 16. 7., s. 1.

Kulisa mluví, kulisa „dělá zed“, Večerník Práva lidu, 1921, r. 10 (30), č. 164, 23. 7., s. 1. $532 \mathrm{p}$.

Lazitch, B. M., Drachkovitch, M. M., 1986. Biographical Dictionary of the Comintern, Stanford, CA: Hoover Institution Press,

Malír, J., Marek, P. a kol., 2005. Politické strany. Vývoj politických stran a hnutí v českých zemích a Československu 1861 2004. Sv. 1 a 2, Brno: Doplněk, 1825 s.

Marek, P., 2016. Proces Karla Švihy (1914), Schelle, K., Tauchen, J. (eds.), Encyklopedie českých právních dějin, 8. Procesy (do roku 1949), Plzeň: Aleš Čeněk, s. 190-195.

Miliony z Ruska, Stráż lidu, 1921, v. 2, no. 78, 16. 7, p. 2-3.

Moskevské peníze na rozbití Československé republiky, Pondèlí. Sportovni věstník, 1921, r. 3, č. 56, 11. 7., s. 1.

Muna, A., 1920. Můj proces. Jak se vyráběji velezrádné procesy v československé republice za vlády "socialistického» ministerského předsedy, Praha: Sociální demokrat, $68 \mathrm{~s}$.

Muna, A., 1919. Ruská revoluce a československé hnutí na Rusi: Řeč soudruha Muny pronesená na schůzi v Dělnickém domě na Kladně 12. ledna 1919, 2. vyd., Kladno: Svoboda, 54 s.

NA Praha, f. MZV, VAMZV, k. 3475 - Organizace podlosti, Národní demokracie, 14. 7. 1921.

NA Praha, f. MZV, VAMZV, k. 3475 - Protikomunistický plakát, Venkov, 22. 7. 1921.

NA Praha, f. MZV, VAMZV, k. 3475 - Kommunismus und Sozialdemokratie, Prager Presse, 24. 7. 1921.

Němci chrání komunisty, Pozor, 1921, r. 28, č. 197, 20. 7., s. 2.

Nový důkaz proti komunistům, Stráž socialismu, 1921, r. 2, č. 118, 19. 7., s. 2.

O těch pěti milionech, Rudé právo, 1921, r. 2, č. 163, 14. 7., s. 7.

Obětovaný národ, Právo lidu, 1921, r, 30, č. 160, 10. 7., s. 1.

Odhalení Engelberta Kučery, Čas (večerník), 1921, r. 31, č. 164, 23. 7., s. 2.

Ochránce zlodějů a koupených duší, Hlas lidu, 1921, r. 36, č. 84, 28.7., s. 3.

Olivová, V., Kvaček, R., 1967. Dějiny Československa od roku 1918 do roku 1945. Praha: Státní pedagogické nakladatelství, $583 \mathrm{~s}$.

Olivová, V., 2000. Dějiny prvni republiky, Praha: Karolinum, 355 s.

Pan Engelbert Kučera, Rovnost, 1921, r. 37, č. 146, 28. 5., s. 5.

Petruševskij, I. P., 1924. Fryné, Plzeň: Nová doba, $150 \mathrm{~s}$.

Pichlík, K., 1991. Bez legend. Zahraniční odboj 1914 - 1918. Zápas o československý program, Praha: Panorama, 419 s.

Podařená společnost, Moravská orlice, 1921, r. 59, č. 121, 31. 5., s. 2.

Podvodník a vyděrač Kučera, Rovnost, 1921, r. 37, č. 195, 16. 7., s. 1-2.

Poselství Čičerinovo Francii a Československá republika, Rovnost, 1921, r. 37, č. 227, 18. 8., s. 2.

Probuzené svědomí, Rudé právo, 1921, r. 2, č. 258, 4. 11., s. 6-7.

Prodali vlastní svědomí a př́íslušníky své strany, Právo lidu, 1921, r. 30, č. 160, 10. 7., s. 1-3.

Prohlášení, Rudé právo, 1921, r. 2, č. 171, 23. 7., s. 1.

Projev soudruha Bely Kuna. „Odhalení“, Rovnost, 1921, r. 37, č. 234, 25. 8., s. 1.

Rázný projev Bely Kuna proti lživé kampani Kučerově, Rudé právo, 1921, r. 2, č. 199, 26. 8., s. 4.

Richtr, K., Probuzené proletářské svědomí a láska k vlasti, Rudé právo, 1921, v. 2, no. 170, 22. 7., s. 2.

Rovnost zase nadává, Stráž socialismu, 1921, r. 2, č. 115, 15. 7., s. 4.

Tomášek, D., 2005. Nevyhlášená válka. Boje o Slovensko 1918-1920, Praha: Epocha, $260 \mathrm{~s}$.

Vatlin, A., 2009. Komintern. Ideji, rešenija, sud'by, Moskva: Rossijskaja političeskaja encyklopedija, 374 s.

Veber, V., 2008. Osudné únorové dny, Praha: Nakladatelství Lidové noviny, $426 \mathrm{~s}$.

Vrbata, J. (ed.), 1997. Sborník dokumentů k vnitřnímu vývoji v českých zemích za 1. světové války 1914 - 1918, 5. Rok 1918, Praha: Státní ústřední archiv, $382 \mathrm{~s}$.

Sommer, K., 1961. O ustaveni marxistické levice a založeni KSČ na Prostějovsku, Prostějov: Komise pro regionální dějiny při OV KSČ, $115 \mathrm{~s}$. 
Sommer, K., 1965. Z bojů dělnické tř́dy a KSČ na Prostějovsku v letech 1921 - 1929, Brno: Blok, $200 \mathrm{~s}$.

Sommer, V., 2007. Bilance jednoho projektu - KSČ a radikální socialismus 1918-1989, Soudobé dějiny 14, č. 4, s. 819-829.

Společná česko-slovenská digitální parlamentní knihovna, stenografický protokol 73. schůze 15. 7. 1921. [Online]. Доступно:

https://www.psp.cz/eknih/1920ns/ps/stenprot/073schuz/s073001.htm (cit. 1. 9. 2020).

Sršatá pokřivená Rovnost, Stráž socialismu, 1921, r. 2, č. 112, 12. 7., s. 5.

Strach před Kučerou, Hlas lidu, 1921, r. 36, č. 81, 21. 7., s. 3.

Synek, J., 1958. Vzpomínky na léta 1917 - 1921, Časopis Matice moravské 77, č. 1/2, s. 198-203.

Tomeš, J., 2005. Průkopníci a pokračovatelé. Osobnosti v dějinách české sociálni demokracie 1878 - 2005. Biografický slovnik, Praha: Česká strana sociálně demokratická, 249 s.

Tomeš, J., 2006. Oldřich Eduard Berger. Biografický slovník českých zemí, 4. Bene-Bez, Praha: Libri, s. 428.

Veselý, J., 1954. Češi a Slováci v revolučním Rusku 1917 - 1920, Praha: Státní nakladatelství politické literatury, 235 s.

Wolker, J., 1954. Próza a divadelni hry, Praha: Státní nakladatelství krásné literatury, hudby a umění, $512 \mathrm{~s}$.

Volkogonov, D., 1994. Lenin. A New Biography, New York: Simon and Schuster, 608 p.

Za sovětské démanty a zlato, Hlas lidu, 1921, r. 36, č. 78, 14. 7., s. 1-2.

Zdrcující odhalení o plánech Moskvy!, Socialistická Budoucnost, 1921, r. 19, č. 160, 12. 7., s. 1.

Zdrcující soud ostravského dělnictva nad komunistickými násilníky, Duch času, 1921, r. 23, č. 206, 2. 8., s. 1-2.

Zlato a diamanty, Nový den, 1921, č. 61, 30. 7., s. 3.

Zubov, A., 2014. Dějiny Ruska. 20. století, 1, Praha: Argo, 949 s.

Žoldnéři nepřátel československé republiky, Stráž socialismu, 1921, r. 2, č. 112, 12. 7., s. 1-2.

\section{SUMMARY}

\section{ВІДОБРАЖЕННЯ СПРАВИ ЕНГЕЛЬБЕРТА КУЧЕРИ В ЧЕСЬКОМУ ДРУЦІ}

prof. Ph.Dr. PaedDr. Павел Марек, Ph.D.

почесний професор кафедри історії філософського факультету університету Палацького в Оломоуці, Чехія

В період Першої світової війни та після виникнення незалежної Чехословаччини (1918) соціалістичний рух у новій республіиі пройшов стадію диференціаиії поглядів, внаслідок чого відбувся розкол чеської соціальнодемократичної партії. Ліва фракиія в 1921 р. відокремилась $і$ заснувала Комуністичну партію Чехословаччини у складі ІІІ Інтернаціоналу. Частиною запеклої внутрішньопартійної, а згодом - міжпартійної боротьби була й так звана справа Кучери, спричинена оприлюдненням інформації про вимогу Комуністичного інтернаціоналу, інтерпретовану Белою Куном, викликати в краӥні пролетарську революиію, що призведе також до ліквідаиії буржуазної Чехословацької Республіки. Повідомлення викликало негативну реакцію громадськості та преси, $i$ керівництво соціал-демократичної партії, орієнтоване на реформи, скористалося иими настроями для дискредитаиії комунізму та комуністичної партії. Перед Першою світовою війною молодий Енгельберт Кучера праџював робітником на Південній Моравї та був одним із затятих функціонерів сочіалдемократичної партії. Після оголошення війни він був призваний до австро-угорської армії та опинився на південному фронті. Тут він незабаром потрапив у російський полон. Після жовтневої революиії 1917 року його мислення змінилося, $і$ він приєднався до радикально налаштованих більшовиків. Вступив до Російської комуністичної партії (більшовиків) $і$ був також засновником Комуністичної партії Чехословаччини на Русі. Проте, повернувиись на батьківщину та розмірковуючи про розвиток подій у радянській Росії в 1917 - 1921 рр. і ситуачію в комуністичному русі Чехословаччини, Кучера переглянув свої погляди. Він відхилився від більшовизму, залишив ліве марксистське крило соиіал-демократії та став критиком насильницьких методів, що супроводжують трансформацію суспільства. Він був переконаний, щяо оптимальним способом утвердження соиіалізму є не революиія, а еволюиія, шлях реформ, якого дотримувалося праве крило чеської соиіал-демократії. Це переконання він зберіг аж до смерті. Змістом представленої статті є уривок життєвого шллху Кучера. У ній представлені дані його найкритичнішого етапу. Справа, спричинена Кучерою, реконструйована за матеріалами окремих статей, опублікованих у друку, що виходив у чеських землях.

Ключові слова: Енгельберт Кучера, політичні партії, Комуністичний інтернаціонал, Чехословацька Республіка, газети. 